\title{
A Modular approach to Customer Satisfaction in Relation to Service Quality
}

\author{
Chaminda Chiran Jayasundara ${ }^{*}$ \\ MACP(UK), MSc(Sheffield), DLitt (South Africa)
}

\begin{abstract}
Continuous improvement of customer (user) service is essential to successful development of business in today's highly competitive, dynamic and complex business environment. There is no exception from it for philanthropic areas including libraries. Thus, this paper reviews the existing literature related to customer satisfaction in relation to service quality to identify the research issues and implications to establish further research avenues in the field. The study revealed that there is a consensus among service marketing researchers on the causal sequence/order of the concepts of customer satisfaction and service quality. Through conceptual improvement and empirical findings of past studies, most researchers have concurred on the fact that quality judgments cause satisfaction, leading to the finding on service quality being the antecedent of customer satisfaction. The formation of satisfaction in relation to service quality is generally based upon some significant theories identified in the literature and it recognised two dominant theoretical paradigms, disconfirmation and performance-only, which can be duly used for modelling customer satisfaction through the service quality perspective in organisations, enabling them to perform possible customer-led service quality evaluations. Secondly, the review more closely examined the potentiality of the prevalent service quality and customer satisfaction models which have been applied in the field of library and information services, such as SERVQUAL, SERVPREF and LibQUAL, understand the customer satisfaction process in the context of service quality. These models were, however, not adequately qualified to confirm their strong applicability for the modelling of the satisfaction process in libraries. Finally, the review concluded with fourteen research issues and their implications relating to library services in demonstrating the void of the prevailing body of knowledge, for new research avenues.
\end{abstract}

\section{*Senior Assistant Librarian, University of Colombo \\ E-mail: chaminda.chiran@gmail.com}


Keywords: Customer satisfaction, User satisfaction, Service quality, User services, Library marketing, User modeling

\section{Service marketing}

The advancement of innovations-particularly, the technical developments of the knowledge era-have made a significant contribution to the market economy in changing the face of its services. The service component of today's market economy is similar in importance to goods. Until recently, service organisations lagged behind manufacturing organisations in their use of marketing strategies. When customers purchase physical goods, they become the owners of these goods because ownership is transferred from the vender to the customer. In contrast, a service customer receives the right to that service for only a specified amount of time (Kandampully 2002), and it cannot be returned (Schnelder \& White 2004). Thus, it is apparent that marketing strategies were not widely used by service organisations in early period of time.

There are also professional service organisations about which professionals previously believed it unprofessional to use marketing strategies to put their commodities up for sale the marketplace (Kotler 2000). There are other service organisations, such as schools, libraries and hospitals, which have not resorted to marketing their services because of the lack of competition they faced, until recently. However, this situation has now changed, and a growing need for service marketing has distinctly emerged in all kinds of service organisations in the service sector. Thus, every service organisation was required to adopt sophisticated marketing strategies to thrive in the sector.

One of the most central distinctions between goods and services is that "goods" are "things" and a "service" is an "act". The fact that a service is a 
process rather than a "thing" means a service firm theoretically has no products, but only interactive processes (Gronroos 2001).

Researchers in this area of service marketing have demonstrated that services are unique and a totally different phenomenon, requiring their own marketing paradigms (Grove, Fisk \& John 2003). The focus of marketing has been revolutionised from the early emphasis on the provision of goods to the new emphasis on the provision of services, based upon the concept of economic exchange. This insinuates that goods should be marketed in a service context, rather than vice versa (Lovelock \& Wirtz 2004). According to Sheth, Sisodia and Sharma (2000), cited in Vargo \& Lusch (2004: 6), "service centered view of marketing is customer centric." Wright (1995: 37) observed that "firms ... need marketing skills to cope with the increasing competitive environment and rising consumer expectations."

The success of the service marketing strategy is, however, linked with the quality of services rendered to customers. It underscores the fact that to reach customers and satisfy them with the services of organisations, there is an urgent need to improve the quality of service.

\section{Service quality}

The number of research studies on different services is rapidly increasing. Among those research studies, one might note that scholars and library administrators in particular have shown considerable interest on issues related to the quality of service and its measurements. Significant conceptual advances have been made by a number of researchers from different academic disciplines. Thus, the theoretical paradigms in conceptualising service quality have always been invigorated by numerous forms of theoretical reasoning, supported by a variety of research studies. 


\section{Defining service quality}

A close perusal of business industries in the 1980s revealed that the concept of service quality had received a great deal of interest as a key strategic factor for product differentiation, and for increases in market share and profits (Bolton, Lemon \& Verhoef 2004). It also revealed that the concept of service quality is primarily based on the quality of services as perceived by customers. When service providers understand how services are evaluated by their customers, it becomes possible to identify how to manage these evaluations and how to influence them in a positive direction (Gaster \& Squires 2003). Although it is difficult to define the authenticity of service quality (Schneider \& White 2004), some researchers have reached a consensus on the fact that service quality should be defined and measured from the customer's perspective. Thus, service quality appears to be predominantly defined from the perspectives of customers in a given service organisation. Many definitions of service quality maintain that this is the result of an evaluation process, whereby customers compare their expectations about a service with their perception of the service to be received (Haywood-Farmer 1988). Zeithaml and Bitner (1996) also define service quality as the "delivery of excellent or superior service relative to customer expectations."

However, the most widely accepted definition of perceived service quality is that it represents the discrepancy between customers' expectations and their perceptions of the service performance, which is basically founded on the expectancy disconfirmation theory (Parasuraman, Zeithaml \& Berry 1994; Tse \& Wilton 1998). Therefore,

Service Quality $(S Q)=$ Perceptions of the performance of service quality $(P)$ Expectations of service quality (E)

This can be mathematically represented as: 
$S Q=P-E$

\section{Nature of service quality}

Two different perspectives of the conceptualisation of service quality can be found in Nordic and North American literature. Researchers such as Brady and Cronin (2001) and Schneider and White (2004), who follow the "Nordic" perspective, have defined the area of service quality in global terms. Some of the earliest Nordic work on conceptualising service quality can be traced back to Gronroos's (1990) technical and functional service quality framework. He argues that service quality can be divided into two generic domains: technical quality that denotes what is provided, and functional quality that denotes how the service is provided.

According to the "North American" perspective, service quality is conceptualised as a "service encounter", which describes service encounter characteristics, such as reliability, assurance, or empathy (Brady \& Cronin 2001). A service encounter is defined as any aspect of a service organisation with which a customer interacts (Driver \& Johnston 2001). The definition of a service encounter is broad and includes a customer's interaction with customer-contact employees, machines, automated systems, physical facilities and other 'service provider' visible elements. When identifying the service quality of a given service, the service encounters must have quality characteristics, such as characteristics of employees' responses and reliability of automated systems. All these quality characteristics, including responsiveness, reliability and other aspects, have been aggregated into domains by some empirical research studies.

For the period of developing the concept of service quality in service industries, a similarity between service quality and customer satisfaction was 
also discovered because these two constructs are structurally similar and are examined using the same framework of expectations and/or perceptions (Hernon 2002).

\section{Customer satisfaction}

The rapidly increasing amount of literature on customer satisfaction straddles many academic disciplines. The review given below initially defines the term customer satisfaction in reference to concepts derived from the prevailing literature, before examining the nature of satisfaction. In this connection, it discusses the theories that are considered as the antecedents and consequences of the construct of customer satisfaction.

\section{Defining customer satisfaction}

The concept of customer satisfaction has been defined in various ways. Zeithaml, Berry and Parasuraman (1993) suggest that customer satisfaction is a function of the customer's assessment of service quality, product quality and price. Woodruff, Cadotte and Jenkins (1983) consider satisfaction to be an emotional reaction by customers in response to an experience with a product or service. However, Iacobucci, Ostrom and Grayson (1995) examine a number of definitions derived from well-developed research studies and distinguish between the concepts of consumer value and customer satisfaction. They state that customer satisfaction, best judged after purchase, is experiential and takes into account the qualities and benefits, as well as the costs and efforts associated with a particular purchase. 


\section{Nature of customer satisfaction}

Understanding the nature of satisfaction is essential for the possible conceptualisation of the customer satisfaction construct. Johnson, Anderson and Fornell (1995), cited in TCRP Report 47 (1999), state that "the modeling of customer satisfaction depends critically on how satisfaction is conceptualized." Mano and Oliver (1993) have identified satisfaction as a cognitive, affective and behavioural reaction connected with a specific service event. Thus, it brings into play the conceptualisation of customer satisfaction, based on the nature of satisfaction founded on the theories that underpin the construct of satisfaction. Therefore, in any search for definitions of customer satisfaction, many notions of customer satisfaction, based on the theoretical nature of satisfaction, emerge. Many of these definitions are founded upon renowned theories that have dominated service quality and customer satisfaction literature in the service marketing area. Some theories that provide the basis for satisfaction can thus be depicted as follows:

1. Performance theory - Customer satisfaction is directly related to the perceived performance characteristics of products or services. Performance is defined as the customers' perceived level of product/service quality, relative to the price they pay. As such, satisfaction is equated with value, where value equals perceived quality divided by the price paid (Johnson, Anderson \& Fornell 1995). On the other hand, some researchers (Cronin \& Taylor 1992: 65) explicate the term customer satisfaction as a function of the performance of service quality attributes. In short, it may be said that customer satisfaction is directly associated with the objectively perceived performance of the product/service.

2. Expectancy disconfirmation theory - This theory has been tested and confirmed in several studies (lacobussi, Ostrom and Grayson 1995; Oliver \& 
DeSarbo 1988), which generally explicate that customers purchase goods and services with pre-purchase expectations regarding anticipated performance. In other words, customers develop expectations of product or service performance prior to purchase. When the product/service is bought and used, the expectations are compared with actual performance, using a 'better-than' or 'worse-than' expression. To simplify it further, once the product or service has been purchased and used, outcomes are compared against expectations.

According to Schneider and White (2004), most researchers agree that the primary model of customer satisfaction is the expectation-disconfirmation model. This model describes a three-step process, as follows.

(i) Customers form expectations about a specific product or service.

(ii) They use that product or service to form perceptions about its performance.

(iii) They assess its perceived performance against their original expectation in order to determine the degree of confirmation with their expectations.

When the outcome matches expectations, confirmation occurs. Disconfirmation occurs when there are differences between expectations and outcomes. Negative disconfirmation occurs when the product/service performance is less than expected. Positive disconfirmation occurs when the product/service performance is better than expected (Johnson, Anderson \& Fornell 1995). Satisfaction is caused by confirmation or by positive disconfirmation of consumer expectations, and dissatisfaction is caused by negative disconfirmation of consumer expectations.

In the expectancy disconfirmation theory, customers may use multiple types of expectations in their satisfaction evaluation processes (Brady, Cronnin \& Brand 
2002: Tse \& Wilton 1988). These types are generally referred to as predictive expectations and normative expectations. Predictive expectations are usually defined as customer beliefs about the level of service that a specific service organisation would be likely to offer. These are frequently used as a standard of reference against which satisfaction judgements are made (Wu et al. 2006). Normative expectations are generally conceptualised as customers' ideas about the level of service that can also be referred to as desires.

Even though the underpinning paradigms of these equity and attribution theories present a better method by which to form customer satisfaction, they have not received the same level of attention in the prevailing literature as the expectancy disconfirmation theory and performance theory. Although these theories-other than the expectancy-disconfirmation and performance theories-show potential, the equity and attribution theories have not been thoroughly researched in the different contextual surroundings. The expectancy disconfirmation and performance theories, however, have been extensively applied in a vast array of research studies in various areas of academic interest. They have further proven their enhanced applicability in modelling service quality and customer satisfaction in different contextual settings.

From the foregoing discussions in relation to customer satisfaction theories, it appears that the performance theory may be more suited to modelling customer satisfaction in university libraries, rather than the expectancy disconfirmation theory, because it stands to question whether or not university clientele have a clear perspective of expectations with regard to library services. In many developing countries, it may be assumed that library patrons are educated with regard to what to expect from the library when they join the university. However, this leads to a new call for research studies in the 
discipline of library and information sciences, to determine which theory is best-suited to this research study.

\section{Conceptual paradigms for customer satisfaction}

This section reviews the existing customer satisfaction paradigms in the light of their theoretical foundations. The purpose of this review is to identify the applicability of the paradigms to the current research. Thus, prior to analysing the pertinent paradigms on the construct of customer satisfaction in relation to service quality, it is necessary to explicate the causal association between customer satisfaction and service quality to understand the causative relationship.

\section{Conceptual relationship between customer satisfaction and service quality}

Due to the urgent need for the development of a working model to elaborate upon the conceptual relationship between customer satisfaction and service quality (Rust \& Oliver 1994), many research studies have been conducted in different areas to determine whether customer satisfaction is influenced by service quality or vice versa. Boulding et al. (199) state that service quality and customer satisfaction are treated as one and the same by the business press. However, a dynamic process model is required to examine the subject from expectation to behavioural intentions. Nevertheless, an attempt to combine customer satisfaction and service quality as one entity or process was considered problematic by Taylor and Baker (1994), who strongly advocate that customer satisfaction and service quality are separate and distinct. Strong arguments have been made by other researchers to consider customer satisfaction judgments to be the very least causal antecedents of service quality (Bitner 1990). 
However, researchers and practitioners alike have exhibited considerable interest in the issues that surround the measurement of service quality and the conceptualisation of a cohesive relationship between quality and satisfaction (Brady, Cronin \& Brand 2002). The most important aspect of this relationship is the causality between the two constructs. Which one is the antecedent to the other? Does satisfaction cause quality judgment, or does quality judgment cause satisfaction? Through the improvement of a conceptual foundation and empirical research findings, most researchers have now concurred that quality judgments cause satisfaction-that is, service quality is the antecedent to satisfaction (Dabholkar, Shepherd \& Thrope 2000; lacobucci, Ostrom \& Grayson 1995). Thus, there is a current consensus among researchers with regard to the causal order of these two constructs.

In considering the dependable statistical correlation between the constructs, the majority of studies have disclosed a linear relationship between customer satisfaction and service quality (Andreassen 2000; Cronin \& Taylor 1992; Parasuraman, Zeithml \& Berry 1988). Most models of service quality, together with SERVQUAL and SERVPREF, also assume a linear relationship between the effect of various causes, including satisfaction and quality. However, a few studies have shown that the relationship between the constructs is non-linear, which is specifically evident in a curvilinear function (Ting 2004). However, customer expectations and their perceptions may vary over time. It follows that the relationship between the constructs may diverge over time, but this has not yet been considered by any study in the field of library and information sciences to map the relationship between satisfaction and quality over the time construct. 


\section{Modeling customer satisfaction in relation to service quality}

The prevailing conceptual literature contains some significant paradigms, such as disconfirmation and performance-only mainly derived from satisfaction theories. As identified by the conceptual relationship between customer satisfaction and service quality, the satisfaction process can be modelled through the paradigms.

\section{Disconfirmation paradigm}

One of the leading paradigms that has dominated the service quality and customer satisfaction literature since 1980 is the disconfirmation paradigm, adapted from the concept of consumer behaviour, which suggests that customers' post-purchase perceptions of a product or service are a function of their pre-purchase expectations (Churchill \& Surprenant 1982; Wu et al. 2006: 224). This is merely based on the expectancy disconfirmation theory. In other words, this model explains that a customer compares his or her experience with pre-consumption expectations (before the consumption of a service) and post-consumption experience (after the consumption of the service). On the basis of this comparison, an attitude of satisfaction or dissatisfaction towards specific service is conjectured.

Adapting the disconfirmation paradigm, Parasuraman, Zeithaml and Berry (1985) proposed a "gap model" operationalised as a comparison of the quality of a service that customers expect to receive from the service provider with the actual level of perceived service performance. According to lacobucci, Ostrom and Grayson (1995: 278), this is referred to as a "disconfirmation paradigm" in the customer satisfaction literature, and as a "gap model" in the service quality literature. 
On par with the disconfirmation paradigm/gap model, service quality is a function of disconfirmation (Lee, Lee \& Yoo 2000; Parasuraman, Zeithaml \& Berry 1985; Parasuraman, Zeithaml \& Berry 1988), which can be modelled as:

Service Quality = $\mathrm{f}$ (disconfirmation)

$S Q=f(d)$

Where SQ = Service Quality; $d=$ disconfirmation

As disconfirmation is Performance $(P)$ - Expectation $(E)$,

$S Q=f(P-E)$

Furthermore, this can be rewritten as

$S Q=\sum_{j=1}^{k}\left(P_{i j}-E_{i j}\right)$

where

$S Q=$ Service quality

$P_{i j}=$ Performance perception of stimulus $i$ concerning attribute $j$

$E_{i j}=$ Expectation of service quality for attribute $j$, which is the relevant norm for stimulus $i$

$k=$ number of attributes

Research studies defining satisfaction hold that customer satisfaction is a function of service quality (Athanassopoulos 2000; Chandrashekaran et al. 2007; Guo, Duff \& Hair 2008).

Customer Satisfaction $=\mathrm{f}$ (Service Quality)

$C S=f(S Q)$

Where CS = Customer Satisfaction; SQ = Service Quality 
Since service quality is a function of disconfirmation, customer satisfaction is also a function of disconfirmation (Davis \& Heineke 1998). Thus,

$C S=f(d)$

Thus, $C S=f$ (performance - expectation)

$C S=f(P-E)$

This dominant theoretical paradigm used in many satisfaction research studies is also termed "disconfirmation paradigm," which has its roots in social and applied psychology (Oliver 1997). Therefore, the disconfirmation paradigm presents its satisfaction judgments in three ways:

1. Satisfaction;

2. Higher satisfaction; and

3. Dissatisfaction.

When performance is greater than the customers' expected level of performance of the service, higher customer satisfaction will result because the service performs better than expected (Harris et al. 2006). Customer dissatisfaction occurs when the performance is less than the customers' expected level of service, as the service performs poorer than the customers' expected level. A confirmation of expectations, or zero disconfirmation, is considered a state of satisfaction. A negative disconfirmation indicates that their expectations were not met and yields a state of dissatisfaction.

\section{Performance-only paradigm}

The performance-only paradigm is also a dominant theoretical paradigm in service quality and customer satisfaction research studies. It appears that customer satisfaction is based on the performance of services, rather than

receiving discrepancy scores between performance and expectations of a 
specific service. As the disconfirmation paradigm has been questioned by some researchers in measuring service quality, the performance-only paradigm has been proposed as an alternative approach. According to the performance-only paradigm, service quality depends primarily on the customers' perceptions of service performance. The emerging literature extensively supports the performance-only paradigm over the disconfirmation paradigm (Boulding et al. 1993 Sutherland \& Drummond 2007). In 1993, Boulding et al. (1993) stated:

Our results are incomplete with both the one-dimensional view of expectations and the gap performance for service quality. Instead, we find that service quality is directly influenced only by perceptions of performance.

It shows that service quality can be conceptualised as performance of the service. Thus, service quality is defined as a function of service performance (Brady Cronin \& Brand 2002; Montoya-Weiss et al. 2003). Accordingly,

Service Quality $=f$ (Performance)

$S Q=f(P)$

Where SQ = Service Quality; $P=$ Performance

Mathematically, this translates to:

$S Q=\sum_{j=1}^{k} P_{i j}$

where

$S Q=$ Service quality

$P_{i j}=$ Performance perception of stimulus $i$ concerning attribute $j$

$k=$ Number of attributes

As customer satisfaction is a function of service quality (Athanassopoulos 2000; Chandrashekaran et al. 2007), it can be presented as 
$C S=f(S Q)$

In addition, research has demonstrated that customer satisfaction is also a function of performance (Davis \& Heineke 1998). Thus,

$\mathrm{CS}=f($ performance $)$

$C S=f(P)$

Given the above, satisfaction results when service performance is higher, and dissatisfaction occurs when service performance is lower. The demarcation of the higher and lower margins is decided by the perception of the customer.

\section{Service quality models for measuring customer satisfaction}

A few conceptual models and paradigms have been postulated in the field of customer satisfaction in relation to service quality. Even though early quality models concentrated primarily on goods, the enormous growth of the service sector in Western economies after the Second World War has resulted in a growing body of literature on service quality. Although the definition and modelling of service quality are generally acknowledged to be more difficult than modelling the quality of goods because of the intangible nature of services (Bergman \& Klefsjo 1994, cited in Hofman \& Worsfold 1996), there are two popular service quality models that are being used worldwide to measure service quality. These are SERVQUAL and SURVPREF.

\section{SERVQUAL Model}

The SERVQUAL (see Figure 1) model was developed by Parasuraman, Zeithaml and Berry (1988), based on the disconfirmation paradigm referred to as the "gap model," underscoring the expectancy disconfirmation theory. The gap model defines service quality as a function of the gap between customers' expectations of a service and their perceptions of the performance of actual service delivery by an organisation. 


\section{CONSUMER}

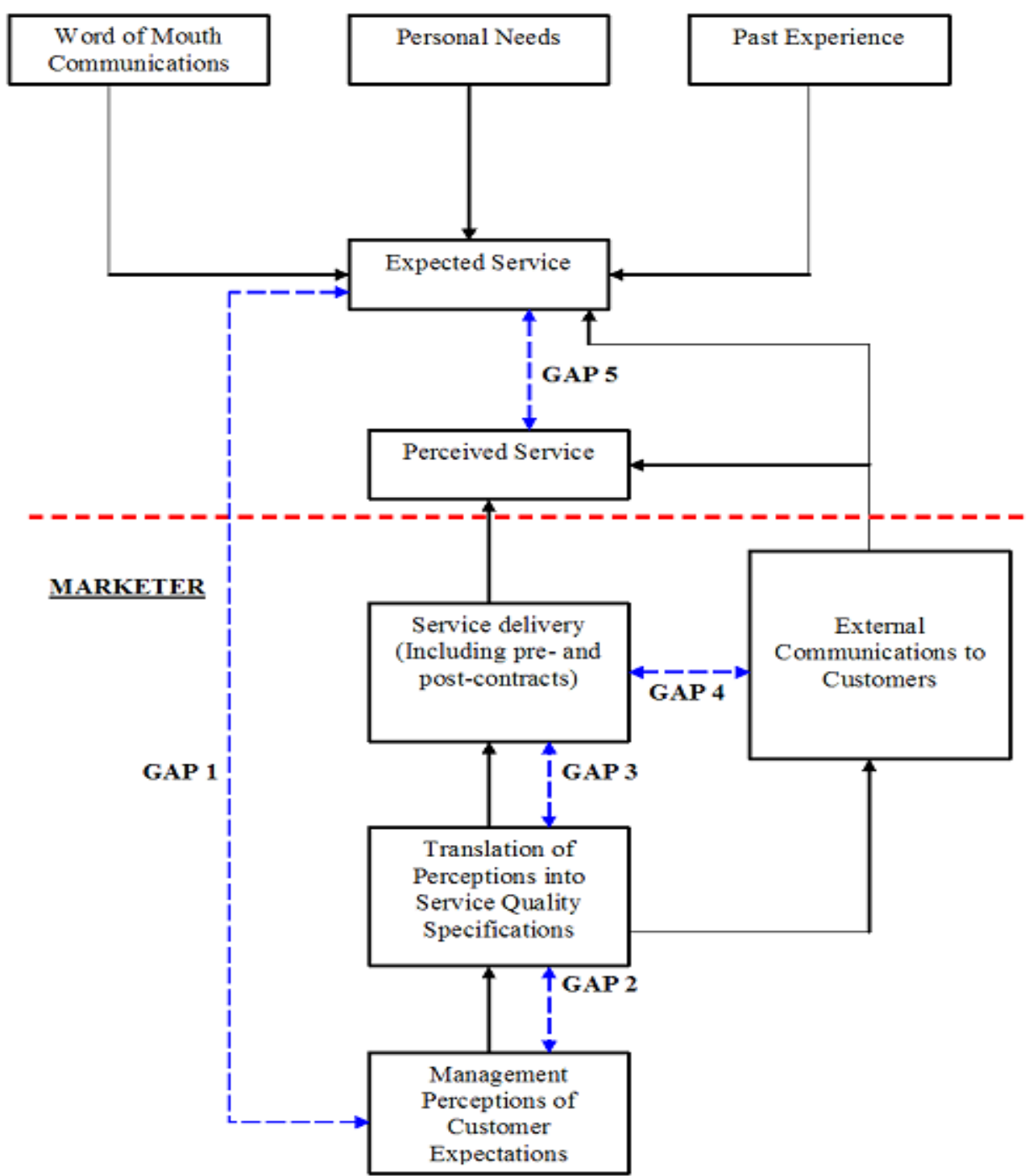

Source: Parasuraman, Zeithaml and Berry (1985: 44)

Figure 1: SERVQUAL model

SERVQUAL quickly became an instrument of choice to measure service quality in the service sector. The initial model consisted of ten domains: tangibles, reliability, responsiveness, competence, courtesy, credibility, security, access, communication and understanding customers (Parasuraman, Zeithaml \& Berry 
1988). However, using several empirical analyses, these three researchers were able to redefine the scale by eliminating some domains from the original scale to consolidate several overlapping quality domains.

Gap 1: The discrepancy between customers' expectations and management's perceptions of these expectations

Gap 2: The discrepancy between management's perceptions of customers' expectations and service quality specifications

Gap 3: The discrepancy between service quality specifications and actual service delivery

Gap 4: The discrepancy between actual service delivery and what is communicated to the customer about the discrepancy

Gap 5: The discrepancy between customers' expected services and perceived service delivery

SERVQUAL is significantly distinct from other conceptual models in that it describes one or more determinants of a quality service encounter (Brady \& Cronin 2001). Although SERVQUAL has been extensively criticised on theoretical, operational and methodological grounds (Buttle 1996), including multicollinearity (Chen, Gupta \& Rom 1994) and psychometric problems (Brown, Churchill \& Peter 1993, it continues to remain the dominant framework for studies of service quality and to be widely applied in different settings (Liou \& Chen 2006; Vos 2003). 


\section{SERVPREF Model}

SERVPREF, developed by Cronin and Taylor (1992), is an instrument to measure service quality and customer satisfaction. It contains the same domains used in the SEVQUAL model. Cronin and Taylor (1992) developed this model to study four service sectors: banking, pest control, dry cleaning, and fast food.

Its framework is based upon the performance theory and is a modification of the SERVQUAL model. The only difference between SERVQUAL and SURVPREF is that the SURVPREF does not take into account customer expectations. It brings into play only customer perceptions of service performance. Therefore, this model does not have a disconfirmation scale, which is the gap between expectations and perceived performance of service. It has only one part, which is the perceived performance of service. In this instrument, customers rate their perceptions of performance of the same attributes that are covered in the SERVQUAL model.

The five domains-tangibles, reliability, responsiveness, assurance and empathy-identified in the SERVQUAL model are equally applicable to the SERVPREF model. According to Cronin and Taylor (1994), SERVPERF can provide managers with a summary overall service quality score, which can then be plotted in relation to time and specific customer segmentations related to consumer characteristics, for example, demographic subcategories and individual constituencies. The SERVPERF scale thus provides a useful tool for measuring the overall service quality attitudes of service managers. However, they suggest that great care should be exercised by managers of service organisations in attempting to derive more specific information from data captured by the SERVPERF scale for strategic decision making (Cronin \& Taylor 1994). 
SERVPREF is less complicated, more concise, more precise and easier to administer than SERVQUAL. However, White, Abels and Nitecki (1994: 40) argue that the SERVQUAL model is the more attractive model because it is more comprehensive and provides better diagnostic information. Nevertheless, SERVPERF explains more of the variation in customer perceptions of service quality than SERVQUAL, as measured by $R^{2}$ statistics. $R^{2}$ can be obtained by regression analysis, wherein the single item overall service quality measure is the dependent attribute, and the deduced five domains are the independent attributes.

\subsection{Conceptual critique}

In reviewing the existing literature, some pertinent and highly relevant arguments against the conceptual foundation of service quality models can be found in the service marketing area. This critique is principally based upon existing criticisms made by marketing, library and information science theorists, and the researcher's own arguments to provide a synthesis of various viewpoints on customer satisfaction and service quality with logical reasoning. This is not to seek conformity with the opinions and arguments already made, but to put forth issues to formulate a coherent conceptual foundation for the current study.

As indicated by the expectancy disconfirmation theory, disconfirmation occurs by subtracting the expectation from the performance, that is, $P-E$. The disconfirmation concept underscores both quality and satisfaction, when modelling customer satisfaction in relation to service quality. However, this disconfirmation concept is rather open to some criticism due to its cognitive nature and algebraic formulation. For example, human beings generally have high expectations and are prone to rate expectations consistently higher than the maximum performance of a given service. As such, it vindicates the fact 
that the disconfirmation paradigm falls short of using the standards for expectations. Conversely, since service quality and customer satisfaction are attitudinal concepts that mainly fall into the category of psychological constructs, van Dyke, Prybutok and Kappelman (1999) (cited in Ladhari 2008) articulate that the disconfirmation $(P-E)$ concept is a poor choice by which to measure psychological paradigms because there is little evidence of customers' actual assessments of service quality, in terms of performanceminus-expectation scores (Kibourne et al. 2004, as cited in Ladhari 2008: 6768).

Brady and Cronin (2001) also critique the $P-E$ concept, suggesting that service quality should be a performance-based construct and more appropriately measured with perceptions, rather than expectations. They question the validity of the $P-E$ specification introduced in the disconfirmation paradigm (Cronin \& Taylor 1992), suggesting this concept is a potentially misleading indicator of service quality perceptions.

The concept of expectation has also been criticised by some researchers, as there is no widely-accepted notion regarding the definition of expectations. "Desires", "wants", "what a service provider should offer", "the level of service that the customer hopes to receive", "adequate service", "normative expectations" and "ideal standards" are some of the explanatory words/phrases subsumed within definitions of expectations (Ladhari 2008). As these different definitions are open to multiple interpretations, it is necessary to delineate a universal definition for the term "expectations" in modelling and evaluating service quality and customer satisfaction. While the effect of expectations on service quality levels is debatable, it is nevertheless interesting to understand what affects expectations. 
There is no complete and universal notion about the best paradigm for predicting customer satisfaction and/or service quality. The disconfirmation paradigm has been challenged by some researchers (Brady, Cronin \& Brand 2002; Cronin \& Taylor 1992; Dabholkar, Shepherd \& Thrope 2000), conveying the view that the performance-only score is an ideal modus operandi for predicting service quality and customer satisfaction. However, following an empirical investigation, Bolton and Drew (1993), cited in Robinson (1999: 24), claim that although performance has been substantiated as a greater determinant of service quality, the disconfirmation paradigm has confirmed improved predictability, compared to the performance-only paradigm. On the other hand, Parasuraman, Zeithaml and Berry (1994), who developed the SERVQUAL model that was built on the basis of the disconfirmation paradigm, proclaim that this model was formulated from focus groups discussions that captured not only the attributes of service quality, but also the underlying psychological process by which customers form judgements on service quality and satisfaction. This is one of the essences of this greatly exclusive model.

Available service quality and customer satisfaction models have generally been criticised for the composition and number of domains they contain. All these measures consist of pre-defined domain attributes that are generic to all service organisations. Babakus and Boller (1992) suggest that service quality may be complex in some industries, and unidimensional in others. Thus, the predefined domains and attributes are not universal and are likely to require contextualisation with respect to the measurements of attributes and the industry being studied (Buttle 1996; Schneider \& White 2004). Hence, a closer look at these models reveals that they underrepresent the construct of customer satisfaction in relation to service quality. In other words, the models do not have a framework required for the holistic understanding of customer satisfaction in relation to service quality in a given environment, as expected. 
These existing models are static and generic in nature and have not been specifically developed for a particular environment, for example, university libraries in Sri Lanka, commercial banks in Singapore, or life insurance companies in South Africa. Thus, these models are common and standard for every type of service organisation.

In the usual course of events, a standard model that can be used for measuring service quality and/or customer satisfaction is an oversimplification and particularly a predefinition of what customers generally seek (Schembri \& Sandberg 2002). Thus, the distinctive characteristics of a particular environment may not be correctly represented in the model. SERVQUAL and SERVPREF can therefore be described as somewhat myopic in their outlook, and their applicability may generate some problems in gauging service quality and customer satisfaction. Thus, it can be limited in practical usage. This creates an urgent need to develop a new framework for measuring customer satisfaction directly from the dynamic environment.

Using a single indicator to denote customer satisfaction has also been questioned in relation to its validity and the reliability (Davis \& Heineke 1998). If a model exercises a single measure for complex constructs, the validity and reliability of the model are considered suspect. Since the SERVQUAL and SERVPREF models utilise a single measure for assessing the construct of customer satisfaction, problems pertaining to validity and reliability may arise. Therefore, as customer satisfaction is a complex phenomenon, a multi-item approach is expected to be used in a model that measures the construct to ensure its higher reliability and validity. In order to overcome the aforementioned problem, the formation of a composite attribute that consists of some attributes denoting the construct of satisfaction can be utilised to designate the customer satisfaction attribute. 
Based on the conceptual critiques made by different researchers in the literature, it may be concluded that both paradigms are distinct, and that there is no universally accepted notion on the optimal paradigm to conceptualise customer satisfaction in relation to service quality. Thus, investigating the two paradigms will enable the researcher to determine which paradigm would be the most appropriate to predict customer satisfaction regarding services provided by university libraries.

\section{Defining quality in libraries}

One of the first researchers to begin the definition process of quality in libraries was Richard Orr (Nitecki 1996). In his pioneering publication of 1973, Orr made a distinction between library quality and the value of library services. He suggests that library quality pertains to "how good the service is," while library value refers to "how much good it does."

The measurement of quality has traditionally been a part of the measurement of effectiveness (Hamburg et al. 1974; Pritchard 1996). The measurements of effectiveness were utilised to evaluate library quality, as library practitioners and researchers in the 1970 s believed that the core of effectiveness was quality. As a result, when the library became more effective, the provision of high quality service to its wider customer community was expected. Orr (1973) (cited in Nitecki 1996) introduces four key areas for library effectiveness-resources, capability, utilisation and beneficial effects-upon which a specific definition could be based. These areas continue to be valid to date. The terms used for quality in the earlier period ranged from "technical efficiency measures to vague statements of goodness but most have focused on goal achievement, efficiency, customer satisfaction, personnel management and the ability of the organization to survive" (Pritchard 1996: 574). 
With the evolution of the quality concept from the view of effectiveness, the need for quality in libraries became very important due to the global digital environment and increasing competition. As a result, libraries have begun to recognise the importance of improving service quality to survive in a competitive world (Cullen 2001). Until recently, however, library quality has been assessed in terms of library collections-size, diversity and comprehensiveness of subject coverage (Dugan \& Hernon 2002; Nitecki 1996). Hernon and Altman (1998) and Shi and Levy (2005) emphasise that most traditional statistics regarding libraries lack relevance and do not measure the library's performance in terms of characteristics important to customers. These statistics have particularly failed to describe the performance of the library or to indicate whether or not the quality of the library is good, indifferent or bad. Moreover, they hardly indicate/recommend/suggest any action that library administrators and other responsible stakeholders could or should take to improve service performance. This partly explains why Dugan and Hernon (2002) perceive quality as a multi-faceted concept that focuses on collections, services and the place of the library in the learning process, within a given context.

In the literature, there is no single, unequivocally accepted definition of quality. Quality in libraries has been perceived from several perspectives. The traditional measures of quality, such as statistics on printed collections, journal holdings and so on, are no longer adequate to reflect library excellence and to impact its aims and objectives (Weiner 2005). These more traditional measures of library quality are considered to be of secondary importance (Nitecki 1996). Thus, a need for an alternative approach to such traditional quality measures has emerged to gauge the quality of libraries more objectively. 


\section{Service quality in libraries}

The application of managerial tools in academic libraries should enable libraries to enjoy the same benefits as in the business sector (Hernon \& Altman 1996; 1998). Successful businesses can model their efficient resource deployment, and likewise, a library can also deploy resources efficiently to reap the same benefits through successful business performances. Businesses generally aim to satisfy their key stakeholders, such as suppliers, customers and employees. Similarly, no library will easily survive if it fails to recognise the needs of its customers and other stakeholders. This underscores the need to provide a broad range of service quality in the library sector to achieve greater customer satisfaction.

There are four models used to measure the effectiveness of library services in different organisations. These models, which have been derived from management literature, are related to quality of services and/or satisfaction of stakeholders. They are:

- Goal attainment model

- Systems resource model

- Internal process or systems model

- Constituency satisfaction model

However, the applications of these models in the library and information service sector have not been significantly successful (Hernon \& Altman 1996). More specifically, when measuring library effectiveness, service quality and satisfaction approaches based on customers' perspectives have not been taken into account in these models. Sabath (1978) argues that customer service levels are generally higher than when a customer would set them and recommends that the service should "banish the costly misconception that all customers seek or need improved service." However, Markham and Aurik 
(1993) explain that selecting when to meet and when to exceed customer expectations is key. Most customers accept a relatively wide range of performance in any given service dimension. These arguments reinforce the opinion that organisations should use a customer-led approach to raise the service quality of libraries and to seek to satisfy customers.

To strive towards the improvement of the services of libraries, and identifying appropriate criteria for evaluating the quality of services rendered to customers is essential. Among the currently available literature, a number of books and research articles published over the last two decades treat the subject of service quality of libraries. One of the earliest and most comprehensive publications among those is "Customer service in the information environment" by Guy St. Clair (1993) (cited in Quinn 1997), which refers to the importance of the views of customers in providing quality service to the wider customer community in libraries. Quinn (1997) emphasises the importance of seeing library users as customers, for they justify the existence of libraries. Providing quality service means being able to view services from the customers' points of view and then meeting their expectations because they form the most important segment in the library community, as those who can define and judge value. A customer is defined as:

A person who brings his/her wants to the organization. It is the organization's function to handle them profitably to both the satisfaction of the customer and the organization. (Peter \& Austin (1987) cited in Sinyenyeko-Sayo 2006:17)

It is apparent that customers are the most crucial group to evaluate the quality of service in any given organisation. Even if service quality is defined in a number of different ways in other academic disciplines, the concept of service quality used in many research studies in library and information sciences is 
that service quality is meant "...to examine the difference between a customer's expectations and the customer's perceived sense of actual performance" (Calvert 2001). Calvert and Hernon (1997) also mention: "Most typically, service quality is defined in terms of reducing the gap between customer expectations and actual service provided." Hernon (2002: 225) concluded that:

...service quality focuses on the interaction between customers and service providers, and the gap or difference between expectations about service provision and perception about how the service was actually provided.

Thus, it appears that the most significant criteria in evaluating service quality are exclusively defined by customers.

According to Hernon and Nitecki (2001), there are many reasons why libraries are interested in service quality. Most libraries are attached to parent institutions: universities, corporations, government agencies and schools. Some parent institutions have made commitments to be accountable to customers and compete for their loyalty. Customers who share information about their expectations also offer an opportunity for libraries or other service providers to establish closer personal contact with them. This relationship should result in libraries providing a better service to customers. It may therefore be construed that library staff are more knowledgeable about their expectations and on how to translate that knowledge into services that satisfy customers and create loyalty.

Hernon and Nitecki (2001) further emphasise that paying attention to service quality generally enables an organisation to develop a partnership with its customers to gain a competitive edge. Besides competing with other service 
providers, present day libraries may find a sharp decline in the statistics depicting in-house library usage .because customers find other avenues to access information, rather than visiting their local libraries. Therefore, a service organisation like the library should have a motivated staff, committed to the provision of excellent service, remotely and locally, and empowered to work directly and continuously with customers in the delivery of such services.

In the case of a library, since the customers are the library users, simple user surveys generally enable library administrators to monitor and assess customer expectations and perceptions systematically in order to formulate a basis upon which to develop an informed approach to improve the services. Calvert and Hernon (1997) describe various measures, such as simple user surveys that library administrators can utilise to measure the level of service quality, by comparing customer expectations with the level of service performance rendered by the staff. They recommend supplementing the survey with focus groups that probe customer expectations more thoroughly, thus gaining more detailed insights into the perceptions of a particular constituent group. They also suggest using focus groups to probe the reactions of library staff to the survey results and to help develop new ways to satisfy customer expectations (Calvert \& Hernon 1997). It thus appears that a phenomenological inquiry would help the researcher to identify the required qualitative insights into what comprises service quality in the problem area.

\section{Customer satisfaction in university libraries}

The university library has been described as the "heart" of the learning community, providing a place for students and faculty to carry out their information searching pursuits to advance their knowledge. The librarians and library support staff provide numerous services to meet the diverse 
informational needs in terms of the requirements and interests of the customers.

According to Filiz (2007), customer satisfaction is an important measure of service quality in libraries. Customers' perceptions about libraries seem to have been largely ignored by library management in developing countries, as is evident from the paucity of literature in the field. The assessment of service quality provides an important feedback for libraries to assess and improve the service provided to its customers. Furthermore, he says:

The survival of a library very much depends on the benefits it brings to customers. Its existence will be in question when customers begin looking for alternatives to library services. One way to show value is by providing quality service. It is therefore important for the library to be aware of changing customer expectations, and to continually strive to provide quality service to its customers. (Filiz 2007: 9)

As cited by Cullen (2001), it was Altman and Hernon (1996) who introduced the idea of "customer satisfaction" in libraries. According to them, service quality in higher education libraries is usually associated with the question of customer satisfaction, which in turn is based on customer perceptions of service quality. The relationship between service quality and customer satisfaction is a complex one, in which the service quality is defined as a component of customer satisfaction. Cullen (2001) further cites Elliot (1995), who also makes use of this term and defines customer satisfaction as the emotional reaction to a specific transaction or service encounter. She points out that satisfaction may or may not be directly related to the performance of the library on a specific occasion. Customers can receive an answer to a query, but be dissatisfied because of an upsetting or angry service provider. 
Conversely, even if the query might remain unanswered, another customer might feel satisfied because the service provider was pleasant, and the helper was interested and courteous.

Employing customer evaluation of library services has been a widely accepted concept since the last decade (Martensen \& Granholdt 2003; Shi, Holahan \& Jurkat 2004). Although the quality element has been firmly established in the academic library sector for at least two decades, measuring customer satisfaction from the service quality perspective has not been comprehensively used in the university library sector. Customer satisfaction is usually not a popular topic in the discipline of library and information sciences, and there are not many research studies yet associated with the university library sector that have been carried out to identify the predictors for satisfaction. Cullen (2001) recounts that research studies analysing customer satisfaction in relation to service quality tended to suggest that very few libraries can understand the importance of quality and satisfaction to retain their customers, in the context of the competitive global digital environment. She further states that the examination of research literature has shown that:

1. There is a body of research on service quality and the role of customer satisfaction, which shows consistent results and patterns of responses by customers in different places and different types of libraries;

2. There are significant gaps between customers' expectations and perceptions of service performance in some of the key areas of library services. These are "quality of collections and access to the collocations", "provision of a study environment", "services and equipment which meet customer needs" and "willingness of staff to help customers"; and

3. Urgent remedial action is needed in the areas identified to increase customer satisfaction, at the micro and macro levels. 
However, there are some models developed and mainly used in business industries to extensively measure service quality to a greater extent and customer satisfaction to a lower extent. These models may also be successfully used to model customer satisfaction in the academic library sector.

\subsubsection{SERVQUAL applications in library sector}

Within the last decade, the focus of the customer-oriented library service concept has been developed in order to support demanding customer needs. The Association of Research Libraries (ARL) in the United States of America has recognised the importance of library assessment as a key driver for change through its principal objective to "describe and measure the performance of research libraries and their contribution to teaching, research, scholarship and community service" (Kryillidou 1998: 8). Therefore, the "service quality" concept was used as one aspect of the library assessment to measure the performance of libraries. Consequently, some researchers such as Nitecki and Hernon (2000) combined the SERVQUAL model with the local environment in which the research problem resides, thus identifying the service quality attributes in university library settings. They used the data collected from surveys and focus groups to modify the SERVQUAL model in order to develop a robust survey instrument for the measurement of service quality. The instrument includes a service quality checklist designed to evaluate several aspects of quality in libraries, with suggestions on how they might best be monitored.

Edwards and Browne (1995) use the SERVQUAL instrument in an academic library setting to determine whether there are differences between customer expectations of service (faculty members) and providers' perceptions of those expectations (librarians). The results indicated that while there were some 
discrepancies between providers' perceptions and customers' expectations, an overall congruence was observable.

Nitecki (1996) conducted a study to determine the applicability of the SERVQUAL instrument to university libraries. Reference, Inter-library Loans, and Reservation Services were studied in this research. The collected data supported the reliability and validity of the SERVQUAL model for use in academic libraries as an accurate measure of service quality. However, the data did not support the existence of five domains of service quality, as reported in the generic SERVQUAL model. The data were less clear for the domains of assurances, empathy and responsiveness. Nitecki's study is, however, primarily important due to its methodological approach and its statistical testing of the validity and reliability of the instrument for use in an academic library setting.

Hernon and Calvert's (1996) study succinctly outlines how academic libraries can implement a service quality programme using a survey instrument. These researchers have carefully developed and pre-tested a questionnaire that measures library customers' expectations. The instrument was purposely designed to be flexible enough so that libraries could adapt it to their local needs, service objectives and policies (Hernon \& Calvert 1996). Through the use of factor analysis on more than 100 attributes in New Zealand, Calvert and Hernon (1996) identified twelve domains of service quality: guidance, waiting times, electronic services, library staff, equipment maintained in good working order, material arriving within a set time, the building and the library environment, library furniture and facilities, and material for course needs. However, this study also failed to support the generic quality domains introduced in the SERVQAUL model. 
All these research studies are important for current and future research projects because of their methodological components, which are based on the disconfirmation paradigm, attitudinal scaling and analytical techniques, specifically for possible modifications to the existing SERVQUAL instrument. Different modified versions of the orthodox SERVQUAL model have been used by several scholars (Filiz 2007; Nimsomboon \& Nagata 2003; Sahu 2007; Sinyenyeko-Sayo 2007) to assess the service quality of university libraries. However, the generic domain structure introduced by the original SERVQUAL model-tangibles, reliability, responsiveness, assurance and empathy-were not discovered by these studies. For example, Filiz (2007) discovered that there are five service quality-related domains: quality of library services, quality of information and library environment, reliability, quality of online catalogue system and confidence applicable to academic libraries. Sahu's (2007) study reflects six domains of service quality: reliability, responsiveness, assurance, access, communications and empathy. Some critical issues pertaining to the reliability of the model are also available.

The research findings from Nitecki's doctoral dissertation (1995), cited in Nimsomboon and Nagata (2003), explain that among the five domains of SERVQUAL, the customers rated reliability as the most important, and tangibles as the least important domain in its factor structure. They further express that "this finding is parallel to those of Srisa-ard (1997), Abdallah (2002) as well as Ford (1994), which found that the customers reported high expectation on reliability." Most findings reflected that reliability is the most important quality domain when evaluating library services, and this finding has also been confirmed in a similar study of Finnish academic libraries, of which the aim was also to investigate academic library services from the customer's point of view (Tuomi 2001). 
The studies referred to above clearly demonstrate that different domain structures specific to each study are easily identifiable. These domains are substantially divergent from the five collapsed domains, which the designers of SERVQUAL and SERVPREF models identified from the applications in other contextual settings. It is therefore evident that due to the changing domain structures from one research project to another, a universally accepted instrument is not available for the assessment of service quality in academic libraries.

However, there is potential for international collaboration on assessing library service quality, as seen from a cross-cultural study comparing perceptions of service quality among library customers in New Zealand and China. The study unequivocally concluded that there are global commonalities in the way customers think about library service quality. Marked similarities in results show that there is perhaps a global set of customer expectations that can be used to measure academic library service quality (Calvert 2001). At the symposium on service quality conducted by the Association of Research Libraries (ARL) in October 2000, Philip J. Calvert compared studies of customer expectations in China and New Zealand to determine whether or not culture is a factor that influences service expectations (Calvert 2001). The results revealed that cultures of nations were not a factor, and that library customer expectations were similar across the countries, such as the United States, New Zealand, Singapore and the People's Republic of China (Calvert 2001). However, the results of other research studies reveal the opposite, pointing out the discrepancies noticeable in this regard from culture to culture (Karatepe, Yavas \& Babakus 2006; Payne-Palacio \& Theis 2005; Spears \& Gregoire 2004). 
Concluding with the applicability of the SERVQUAL model in the library and information service sector, an assortment of results connected to different domain structures and attributes were produced. It is therefore clear that SERVQUAL is not the best model for measuring the customer satisfaction construct and/or service quality construct in the discipline of library and information sciences. Moreover, current research trends, in relation to customer satisfaction in the area of service marketing, suggest that SERVQUAL, due to its primary concern with gauging service quality in a given scenario, has not been used to measure customer satisfaction to any great extent. In this context, it is pertinent to point out that, though SERVQUAL is a generic model common to all kinds of organisations, it requires thorough customisation for use within library settings. As a consequence, LibQUAL has emerged to fill the deficiency gaps of the SERVQUAL model.

\subsubsection{LibQUAL}

Since the 1990s, many researchers have tried to use SERVQUAL to measure library service quality in different settings, but failed to produce reliable and valid results. LibQUAL, which is a modified version of SERVQUAL, was designed by library and information science researchers on the basis of the underlying methodology of SERVQUAL. LibQUAL is a Web-administered library service quality assessment protocol that has been used worldwide in different types of libraries (Cook, Heath \& Thompson 2001). In October 1999, LibQUAL was developed into a tool for library service quality assessment by the Association of Research Libraries (ARL) in the United States of America. The domains of the tool are as follows:

- Affect of Service: It combines three of the service domains identified by SERVQUAL into one. These domains are assurance, empathy, and reliability; 
- Reliability: Ability to perform the promised service dependably and accurately;

- Access to Information: Access is ensured through the provision of comprehensive collections and ubiquity of access, or the provision by all means possible of barrier-free access to information when needed;

- Library as Place: Ability to meet community requirements and provide space for study, collaboration, or rendezvous; and

- Self-reliance: Ability to foster self-reliant, information-seeking behaviour through instruction, mentoring, signage and other means (Cook, Heath \& Thompson 2001).

LibQUAL is a suite of services that libraries use to solicit, track, understand, and act upon customers' opinions of service quality (LibQUAL 2008). It has been rigorously tested through a Web-based survey combined with training to help libraries assess and improve their services, change their organisational culture, and market their services. The goals of LibQUAL are to:

- "Foster a culture of excellence in providing library services,

- Help libraries better understand customer perceptions of library service quality,

- Collect and interpret library customer feedback systematically over time,

- Provide libraries with comparable assessment information from peer institutions,

- Identify best library service practices,

- Enhance library staff members' analytical skills for interpreting and acting on data" (LibQUAL 2008). 
The original LibQUAL presents 41 statements, accompanied by a three-column rating format consisting of minimum service expectations, desired service expectations, and the perception of service performance of the library reviewed. Heath, Cook and Thompson (2001) assert that these statements examine three domains (affect of service, reliability or service efficiency and tangibles) and introduce a fourth domain: resources. These authors claim that these attributes better reflect the service quality domains of research libraries than the original SERVQUAL set of factors and domains developed across service industries.

After rigorous testing of the LibQUAL protocol over a three-year period, the survey was standardised to include the following key elements (LibQUAL 2008):

- Twenty-two core items spanning 3 domains - Affect of Service, Information Control, and Library as Place;

- Eleven additional items covering information literacy outcomes, general satisfaction with library service, and library usage trends;

- General demographic items; and

- A comments box for open-ended customer comments.

A related case study by Walters (2003:98) highlights several advantages over earlier assessment instruments. He finds that:

- $\quad$ LibQUAL is designed to elicit responses from a random sample of both library customers and non-customers;

- It accounts for respondents' minimum and desired levels of performance, rather than relying solely on their perceptions of current conditions;

- It provides multiple benchmarks for the comparison of institutions; 
- It meets established criteria for reliability and uses questions derived from in-depth interviews with library patrons; and

- It identifies the various facets of perceived quality and provides an overall rating for each.

The original five domains of the LibQUAL were changed with the passage of time (see Table 1), and in 2003, this resulted in three domains. In the LibQUAL model, "Library as Place" refers to the physical environment, "Affect of Service" reflects the warmth, empathy, reliability and assurance of library staff, and "Information Control" is the ability to control the information universe efficiently (LibQUAL 2008).

Table 1: Domains of library service quality in LibQUAL

\begin{tabular}{|l|l|l|l|}
\hline \multicolumn{1}{|c|}{2000} & \multicolumn{1}{|c|}{2001} & \multicolumn{2}{c|}{2003} \\
\hline 41 items & 56 items & 25 items & 22 items \\
\hline Affect of service & Affect of service & Service affect & Service affect \\
\hline Reliability & Reliability & $\begin{array}{l}\text { Library as a } \\
\text { place }\end{array}$ & $\begin{array}{l}\text { Library as a } \\
\text { place }\end{array}$ \\
\hline Library as a place & Library as a place & Personal control & $\begin{array}{l}\text { Information } \\
\text { control }\end{array}$ \\
\hline $\begin{array}{l}\text { Provisions of } \\
\text { collections }\end{array}$ & Self-reliance & $\begin{array}{l}\text { Information } \\
\text { access }\end{array}$ & \\
\hline $\begin{array}{l}\text { Access to } \\
\text { information }\end{array}$ & $\begin{array}{l}\text { Access to } \\
\text { information }\end{array}$ & & \\
\hline
\end{tabular}

Source: LibQual 2008

This model is also common to all forms of libraries, and thus, it is a generic model, which is inflexible for deep customisation for a specific kind of libraryfor instance, the university library or the public library. LibQUAL's factor structure has been changed several times to form a new generic model, which was implemented in 2003. As the conceptual formation of this model is the 
same as SERVQUAL, the issues pertaining to the conceptual criticisms are also commonly applicable to this model.

\section{SERVPREF applications in library sector}

SERVPREF is merely a subset of SERVQUAL. The rationale behind the development of this instrument was that:

(i) measuring customers expected service level, prior to the service delivery, is impossible.

(ii) measurement of expected service level after service delivery may be inaccurate, as the customers' expectations, by then, have already been biased by the service.

Using this rationale, Cronin and Taylor (1992) proposed an alternative instrument, which used 22 questions with respondents' perception-only scores to measure service quality instead of SERVQUAL's disconfirmation scores. The SERVPERF instrument is therefore identical to SERVQUAL, with the exception that SERVQUAL has 44 items (22 items for expectation of service quality and 22 items for performance of service quality), while SERVPERF has 22 items addressing only actual performance. A replicated study with the new dataset also showed the superiority of the performance-only approach as a measurement of service quality (Brady, Cronin \& Brand 2002; Einasto 2009: 14).

However, the SERVPREF model has not been adequately researched in the contextual settings of libraries. The attributes nevertheless covered by both models, that is, SERVQUAL and SERVPREF, are the same and seem appropriate for libraries. White, Abels and Nitecki (1994), state that both models are flexible, and they can be modified to suit special libraries. However, according to Hernon and Nitecki (2001) and Martin (2003: 19), SERVPREF has rarely been 
used in libraries, and researchers have shown a clear preference for SERVQUAL, which has the facility for broad application to service industries. The obvious theoretical and methodological formation of these models have been criticised by a number of researchers and have not been resolved to date.

\section{Contextual research critique}

A number of critiques have been presented regarding the SERVQUAL, LibQUAL and SERVPREF models in the last two decades by researchers in the service marketing area belonging to different academic disciplines. Apart from the conceptual deficiencies described above, contextual weaknesses that include operational and functional deficiencies and limitations, can also be identified in these measurements.

\section{Operational critique}

All investigators work with predetermined scales when using measurement instruments. It has been demonstrated by several authors in the fields of psychology (Allport 1961), business (DeSarbo et al. 1994) and artificial intelligence (Cronin \& Taylor 1992) that scales for the measurement of perceptions are not symmetrical, and the length of each interval within the scale may not be equal. This point indicates a drawback, similar to a conversion of a Likert scale into an ordinal scale.

SERVQUAL, SERVPREF and LibQUAL measures are static, in that they do not consider the history of the service, and they fail to capture the dynamics of the changing expectations. Parasuraman, Zeithaml and Berry (1994) point out that some respondents may not possess the necessary knowledge to respond to some of the SERVQUAL and SERVPREF items and therefore record a rating of 
'four' (the mid-point of a seven-point scale) on the perceptions scale. The final gap score may then indicate something other than what it should mean.

The other apparent drawback in SERVQUAL and SERVPREF models is also related to their measurement scales of constructs. Both models use a Likert scale to measure service quality attributes and domains, while a semantic differential scale is utilised to measure overall satisfaction. Different measurement scales may, however, lead to some empirical errors because of its measurement inconsistency. Furthermore, as the SERVQUAL scales have no verbal labels for scale points two to six, Nanayakkara (2008: 43) suggests that if a scale does not have verbal labels, respondents may overuse the extreme end-points that have verbal labels. This will particularly affect the 10-point semantic differential scale due to its enormity. Verbal labelling of all of the scale points may be less subject to such bias and may accurately record the respondent's intended response.

In criticising the application domain of the SERVQUAL model in the library sector, some arguments against the validity of the model can also be found. Criticisms include the use of different scores, applicability, dimensionality, lack of validity and so on. Nitecki and Hernon (2000), cited in Hernon and Calvert (2005: 382), say:

...given the focus on instrument development, the investigators did not pursue external validity or the generalisability of findings to the customer or broader university community. Nor did they limit the study to those statements having local relevance. Rather, they developed an instrument consistent with ones discussed in the literature review. 
Carman (1990: 34) found a larger number of domains and highlighted the multi-faceted nature of some services. He further says that the SERVQUAL scale fails to elicit the importance of all five factors in some special cases of tyre stores, placement centres and dental clinics. In the library sector, Andaleeb and Simmands (1998), cited in Cook, Heath and Thompson (2001: 148), point out that "various studies in the information service sector have also demonstrated that the domains introduced in SERVQUAL have not been confirmed." Furthermore, they argue that additional factors need to be integrated to SERVQUAL to measure some other important domains on customers' perspectives of library service quality. Hernon and Nitecki (2001: 698) stress that

...believing that SERVQUAL does not sufficiently address local expectations and priorities, Peter Hannon and his colleagues in the United States and New Zealand developed a generic set of expectations that individual libraries could use as a guide for deciding on those statements that they might treat as priorities.

Furthermore, they emphasise that "central to their approach is the belief that whatever expectations probed should result from local review and the input of library staff and some customers." Their research was focused on the library or service location and did not attempt to determine the relevance of statements across institutions or over time (Hernon \& Nitecki 2001: 698).

As LibQUAL is currently the most popular and widely used assessment tool in different libraries, even though it was principally developed for research libraries, its theories and applications in library assessment processes warrant further analysis. As previously noted, LibQUAL was introduced into the library sector as an expansion of the SERVQUAL model. Accordingly, the customers' 
perceived quality of library services in LibQUAL is the customers' judgment about their overall experiences with the services. This determination is based on the degree and direction of discrepancy between the customer's perceptions and expectations. The underlying theory of SERVQUAL and LibQUAL is the same, even though there are some modifications in its domain structure. Therefore, it is quite apparent that the same theoretical inconsistencies and issues apply to both instruments.

\section{Functional critique}

From the point of view of a decision making process, instruments based on SERVQUAL do not show a clear linkage between customer satisfaction and managerial decisions for the reason that the output cannot be easily translated into decisions. There is no suggestion on how management can use these instruments as a strategic lever and better decide what in fact needs to be changed, how to connect these measures to changes and goals achieved, and how customer expectations are updated, because it is widely known that perceptions vary over time.

LibQUAL is one of the instruments used to measure library service delivery performance, but the literature reports that there are functional issues, such as costs in developing and administering the survey on an individual and institutional basis (Hiller 2001). Walters (2003) also raises two questionable assumptions that are not clear in the LibQUAL instrument: first, whether the library customers have the necessary expertise to make accurate assessments of quality, and second, whether perception serves as valid indicators of objective conditions. This suggests that, given the above reasons, students' lack of experience with academic libraries may result in an inability to make valid assessments of quality. Some researchers such as Cuthbert (1996) argue that library customers can recognise excellent service from poor service only 
once they have been exposed to both levels of service, and also only if they are taught the difference between high and low quality. For example, in the case of LibQUAL, responses of the faculty staff may be significantly more useful than those of the undergraduate students (Walters 2003).

Rajan and Ravi (2001), cited in Sahu (2007), point out some limitations and deficiencies in SERVQUAL, for example, because the domain structure of the model has not been confirmed by rigorous studies and replicative studies carried out in the field of library and information sciences. The underlining cause is that this model was originally designed for the commercial environment and not for non-profit philanthropic service industries, like libraries and museums. Moreover, they suggest that some adaptations must be completed in order to design a more sophisticated, reliable and effective instrument ensuring higher applicability in the library sector.

Even though service quality is a new concept in the library and information service sector in Sri Lanka, most academic libraries have now begun to enhance service quality from customers' perspectives and the quality standards introduced by ISO, the Sri Lanka Standards Institute (SLSI), and QAA. However, there is a dearth of research studies in the area of customer satisfaction from the service quality perspective, not only in Sri Lanka, but also in the South Asian region. More attention is therefore needed to substantiate the applicability of these models in different cultural settings in the world.

\section{Research implications}

The above discussion showed numerous areas wherein research relating to customer satisfaction, in terms of service quality in university libraries, was needed. On the whole, fourteen significant research issues of academic and managerial importance were identified from the review (see Table 3). Each of 
these areas was identified based on issues arising from either the theoretical basis of existing research or on the empirical basis. Table 3 summarises these implications.

Table 3: Issues identified from the review and research implications for the study

\begin{tabular}{|c|c|}
\hline Research issue & Research implications \\
\hline $\begin{array}{l}\text { 1. Conceptual foundation of } \\
\text { customer satisfaction }\end{array}$ & $\begin{array}{l}\text { 1. Whether or not to use the disconfirmation }(E-P) \text { paradigm or } \\
\text { performance-only }(P) \text { paradigm }\end{array}$ \\
\hline $\begin{array}{l}\text { 2. Development/modification of } \\
\text { exiting models }\end{array}$ & $\begin{array}{l}\text { 2. Whether or not to develop a new model for measuring customer } \\
\text { satisfaction in relation to service quality or to modify one of the } \\
\text { existing tools for the purpose }\end{array}$ \\
\hline $\begin{array}{l}\text { 3. Relationship between the } \\
\text { constructs of customer } \\
\text { satisfaction and service quality }\end{array}$ & $\begin{array}{l}\text { 3. Whether or not to assume that the relation between customer } \\
\text { satisfaction and service quality is linear or non-linear }\end{array}$ \\
\hline $\begin{array}{l}\text { 4. Prediction of customer } \\
\text { satisfaction in relation to service } \\
\text { quality }\end{array}$ & $\begin{array}{l}\text { 4. As the prediction of customer satisfaction has not been } \\
\text { incorporated into the major part of the existing models, even if the } \\
\text { key role of these models is to measure service quality, what } \\
\text { precautions need to be undertaken for the research design to } \\
\text { predict customer satisfaction in relation to service quality? }\end{array}$ \\
\hline $\begin{array}{l}\text { 6. Dimensionality of service } \\
\text { quality }\end{array}$ & $\begin{array}{l}\text { 6. Whether to use the same attributes and domains presented in } \\
\text { the SERVQUAL/SERVPREF and LibQUAL models or to generate a } \\
\text { deductive and/or inductive approach of item generation from the } \\
\text { real life phenomenon }\end{array}$ \\
\hline 7. Resource quality & $\begin{array}{l}\text { 7. As the library consists of tangible information resources and the } \\
\text { demand for these materials from customers is high, how do we give } \\
\text { significant attention to receiving customer perceptions regarding } \\
\text { resource quality intangibly? }\end{array}$ \\
\hline 8. Measurement scale & $\begin{array}{l}\text { 8. Whether or not to use a semantic differential scale or a Likert } \\
\text { scale for attitudinal questions } \\
\text { 9. Whether or not to use a five-point, seven-point or ten-point } \\
\text { scale. } \\
\text { 10. Whether or not to use the same point scale for } \\
\text { measuring/identifying service quality, purposive and situational } \\
\text { attributes and overall satisfaction } \\
\text { 11. Whether or not to use extremity labels }\end{array}$ \\
\hline 9. Research approach & 12. Whether or not to use the case study or survey method. \\
\hline
\end{tabular}


Issue 01: Since there are some theoretical paradigms underlying customer satisfaction, it is necessary to decide which of the paradigm/s are appropriate for the research problem of this study. The disconfirmation (gap score) paradigm and performance-only paradigm have particularly shown their capability to model service quality and customer satisfaction. However, a compelling argument raised by Bolton and Oliver (1989), cited in Bolton in Drew (1991), states that only customers' assessment of continuously provided services, which may depend on performance evaluation, deserves attention. As libraries are services provided continuously and considered in general to be a public service, it is important to research this issue. Some studies prove the superiority of perception-only measures in terms of predictive power and ability to explain the variance in overall perceptions of service quality (Cronin \& Taylor 1992). However, the researchers who developed SERVQUAL do not discard their model because the conceptualisation of service quality as a perception-expectation gap is not only rooted in a dominant theory in service marketing, but has also been supported in their focus group studies.

Issue 02: Many researchers (Brown \& Swartz 1989; Carman 1990; Bojanic 1991; Babakus \& Mangold 1992) have applied the SERVQUAL model to various business and non-business industries. SERVQUAL quickly became a promising instrument for measuring service quality and customer satisfaction in the service sector. According to White and Abels (1995: 38):

SERVQUAL has become the most widely used instrument for measuring service quality in profit and non-profit organizations. No other (marketing) instrument has been tested as stringently and comprehensively as SERVQUAL 
Despite the unprecedented support for the use of SERVQUAL, its methodological approach has been widely criticised, and some researchers agree that the performance-only paradigm is superior to the disconfirmation paradigm (Cronin \& Taylor 1992: 64-65). It generates mixed results and raises the question as to which model is better suited for modelling/measuring customer satisfaction. It is apparent, therefore, that there is still no generally accepted, universal model, and thus, it points to the development of a new model for a selected industry based on the underpinnings of theoretical paradigms.

Issue 03: Reviews of the existing literature on customer satisfaction in relation to service quality suggest that the current understanding of the relationship between customer satisfaction and service quality is problematic (Taylor \& Baker 1994, cited in Jamal \& Naser 2002). Even if different models have been developed and extended to provide better measurements of service quality and customer satisfaction, a consensus on the relationship between these two constructs cannot yet be found. Although many researchers have proved the linear relationship between these two constructs (Andreassen 2000; Cronin and Taylor 1992), some researchers have started to explore the possibility of a non-linear relationship between customer satisfaction and service quality (Ting 2004). A study by Basadur and Head (2001) (cited in Ting 2004) argues that the relationship between these constructs is a curvilinear function. Ting's (2004) findings supported the notion by empirical investigation of a curvilinear relationship between customer satisfaction and service quality. This conflicting empirical evidence highlights the need for research on the causality between customer satisfaction and service quality.

Issue 04: In order to provide a greater customer service, libraries can help enhance service quality by predicting customer satisfaction in relation to 
service quality. The increased importance of library services today motivated the researcher to understand more thoroughly how this is evaluated by service customers, and how their evaluations affect overall customer satisfaction. From the conceptual and contextual research reviews, it is very clear that there are no well-accepted and well-established conceptual models for predicting customer satisfaction in relation to service quality, even though there are some generic models, such as SERVQUAL, SERVPREF and LibQUAL. These models particularly focus on service quality and have not given priority to the construct of customer satisfaction.

Issue 05: As the existing models are static in nature, they fail to accommodate the inherent dynamism of customer satisfaction and service quality in a given context. They seek objective measurements for universal prediction in a robust positivistic approach. However, the attempt has failed to present a more objective measurement because of the models' static and generic natures. The focus of the delineation of customer satisfaction is more general, and the research therefore neglects the customers' real perspectives in relation to their specific contextual environments. Consequently, there should be a genuine reflection of the customers' view on satisfaction in relation to service quality. The pre-developed theoretical framework based on the prevailing literature, which consists of the customer satisfaction construct with pertinent attributes and domains, can be validated and/or redefined with the customers' views on satisfaction and service quality in a given environment.

Issue 06: In 1990, Carman (1990) found that the SERVQUAL attributes and domains were inconsistent across industries and suggested that the scale should be customised for each service industry. In addition, many researchers (cited in Cook, Heath \& Thompson 2001; Carman 1990) have applied SERVQUAL in various industrial settings, but failed to confirm its five-domain 
structure. As SERVQUAL, LibQUAL and SERVPREF are generic models, they have not been particularly developed for a specific industrial sector, for example, university libraries in Sri Lanka. Furthermore, since the service quality instruments indicate that the factor structure may show a discrepancy across different industries (Babakus \& Boller 1992; Badri, Abdulla \& Al-Madani 2005; Schneider \& White 2004), researchers such as Cronin and Taylor (1994: 130) propose:

.... to assess the factor structure implicit in a data set derived from SERVQUAL and SERVPREF measures to ensure that the hypothesized five- factor structure identified by PZB (1998) can be replicated specific to their own research setting. They therefore recommend customizing the attributes and domains in accordance with the industrial circumstances.

Issue 07: Most services fall between tangible and intangible continuumstangible includes materials, while intangible refers to personnel (Schneider \& White 2004). In academic libraries, customers receive a combination of both materials and personnel services. The material service refers to one that is more tangible in nature, and they are more technical and objectively measurable products, such as books, journals and so on. It is therefore apparent that library services lie closer to both material and personnel continuums. Thus, it implies that the balance between material service (tangibles) and personnel service (intangibles) is essential in libraries to provide a better service to customers (Schneider \& White 2004) and to meet customer needs effectively.

Issue 08: It is apparent that the measurement scales used in SERVQUAL and SERVPREF are also dubious. There is no perfect agreement between these instruments on the issue of measuring attributes by a Likert scale or a semantic 
differential scale, or by a Likert scale with overall satisfaction measured by a semantic differential scale. SERVQUAL and SERVPREF use these two different scales-that is, the Likert scale and semantic differential scale. Since these two scales are used in one instrument, the researcher believes that this may lead to some empirical miscalculations. On the other hand, a number of researchers raise the question as to what is the most appropriate number of scale points that will maximise reliability (Glimore \& Carson 1992).

Issue 09: According to past research, many studies were based on the case study method, limiting them to a single organisation. The method has not been expanded to cover a number of similar organisations to generalise the research findings. It thus raises the question as to which method should be used for this research, whether it is the case study or survey method.

In the light of the significant issues identified in the reviews, a new research study that may help to overcome concerns raised over the conceptual and contextual settings is warranted.

\section{Conclusion}

The paper reviewed research studies relating to customer satisfaction and service quality in the library and information service sector. Among those, a few studies were found to address service quality and customer satisfaction in the academic library sub-sector, with little or no consistency in the findings. On the whole, service quality and customer satisfaction evaluations in the existing literature reveal numerous conflicting results, as no study has simultaneously compared the relative efficacy of the two paradigms identified from the conceptual review- disconfirmation and performance-only-relating to the university library environment. This clearly identified gap should be addressed 
in a comprehensive study using both qualitative and quantitative methodologies.

\section{References}

Allport, FH. 1961. Theory of perception and the concept of structure. New York: John Wiley.

Andreassen, TW. 2000. Antecedents to satisfaction with service recovery. European Journal of Marketing, 34(1/2):156-75.

Babakus, E \& Boller, GW. 1992. An empirical assessment of the SERVQUAL scale. Journal of Business Research, 24(3): 253-268.

Babakus, E \& Mangold, WG. 1992 Adapting the SERVQUAL scale to hospital services: an empirical investigation. Health Services Research, 26(6): 767786.

Bernat, R. 2005. The systems resource model. Available: http://www.strategiccontrol.24xls.com/en126 (Accessed 12 December, 2007).

Bitner, MJ. 1990. Evaluating service encounters: the effects of physical surroundings and employee responses. Journal of Marketing, 54(2): 69-83.

Bolton, RN \& Drew, JH. 1991. A multi stage model of customers' assessments of service quality. Journal of Consumer Research, 17(4): 375-385.

Boulding, W, Kalra, A, Staelin, R \& Zeithaml, VA. A dynamic process model of service quality: from expectations to behavioral intensions. Journal of Marketing Research, 30(1): 7-28.

Brady, MK \& Cronin, JJ. 2001. Some new thoughts on conceptualizing perceived service quality: a hierarchical approach. Journal of Marketing, 65(3): 34-49.

Brady, MK., Cronin, JJ \& Brand, RR. 2002. Performance-only measurement of service quality: a replication and extension. Journal of Business Research, 55: 17-31.

Brown, S \& Swartz, T. 1989. A gap analysis of professional service quality. Journal of Marketing, 53(2): 92-98. 
Brown, TJ., Churchill, GA \& Peter, JP. 1993. Research note: improving the measurement of service quality. Journal of Retailing, 69(1): 127-139.

Buttle, F. 1996. SERVQUAL: review, critique, research agenda. European Journal of Marketing, 30 (1): 8-32.

Calvert, PJ \& Hernon, P. 1997. Surveying service quality within university libraries. Journal of Academic Librarianship, 23: 408-415.

Calvert, PJ. 2001. International variations in measuring customer expectations. Library Trends, 49(4), 732-757.

Carman, JM. 1990. Consumer perceptions of service quality: an assessment of SERVQUAL dimensions. Journal of Retailing, 66(1): 33-56.

Chen, IJ., Gupta, A \& Rom, W. 1994. A study of price and quality in service operations. International Journal of Service Industry Management, 592: 2333.

Childers, T \& Van House, NA. 1993. What's good? Describing your public library's effectiveness. Chicago: American Library Association.

Churchilll(spelling), GA \& Surprenant, C. 1982. An investigation into the determinants of customer satisfaction. Journal of Marketing Research, 19(4): 491-504.

Clow, KE \& Vorhies, DW. 1993. Building a competitive advantage for service firms: measurement of consumer expectations of service quality. Journal of Services Marketing, 7(1): 22-32.

Cook, C., Heath, FM \& Thompson, B. 2001. Users' hierarchical perspectives on library service quality: a "LibQUAL+" study. College and Research Libraries, 62: 147-153 Available:

http://www.ala.org/ala/acrl/acrlpubs/crljournal/backissues2001b/march0 1/cook.pdf (Accessed 20 November 2007).

Cronin, JJ \& Taylor, SA. 1992. Measuring service quality: a re-examination and extension. Journal of Marketing, 56(3): 55-68.

Cronin, JJ \& Taylor, SA. 1994. SERVPERF versus SERVQUAL: reconciling performance-based and perceptions-minus-expectations measurements of service quality. Journal of Marketing, 58(1): 125-131. 
Cullen, R 2001. Perspectives on user satisfaction surveys. Library Trends, 49(4): 662-687.

Cullen, R. 1998. Does performance measurement improve organisational effectiveness? A post-modern analysis. In Wressell, P. (ed). Proceedings of the 2nd Northumbria International Conference on Performance Measurement in Libraries and Information Services, Longhirst Hall, Northumberland, 7-11 September 1997, Information North: 3-20.

Cuthbert, PF. 1996. Managing service quality in HE: is SERVQUAL the answer? Part I. Managing Service Quality, 6(2): 11-16.

Dabholkar, PA., Shepherd, CD \& Thrope, DI. 2000. A comprehensive framework for service quality: an investigation of critical conceptual and measurement issues through a longitudinal study. Journal of Retailing, 76(2): 131-139.

Davis, MM \& Heineke, J. 1998. How disconfirmation, perception and actual waiting times impact customer satisfaction? International Journal of Service Industry Management, 9(1): 64-73.

DeSarbo, WS, Huff, L, Rolandelli, MM \& Jungwhan, C. 1994. On the measurement of perceived service quality: a conjoint analysis approach. In Rust, R.T, Oliver, R.L (Eds), Service Quality: New Directions in Theory and Practice. Thousand Oaks: Sage: 201-22.

Driver, C \& Johnston, R. 2001. Understanding service customers: the value of hard and soft attributes. Journal of Service Research, 4(2): 130-140.

Dugan, RE \& Hernon, P. 2002. Outcomes assessment: not synonymous with inputs and outputs. Journal of Academic Librarianship, 28: 376-380.

Edwards, S \& Browne, M. 1995. Quality in information services: do users and librarians differ in their expectations. Library and Information Science Research, 17(1): 63-82.

Feinburg, RA \& de Ruyter, K. 1995. Consumer-defined service quality in international retailing. Total Quality Management, 6 (1): 61-67.Filiz, Z. 2007. Service quality of university library: a survey amongst students at Osmangazi University and Anadolu. Available:

http://eidergisi.istanbul.edu.tr/sayi5/iueis5m1.pdf (Accessed on 23March 2008).Finn, DW \& Lamb, C. 1991. An evaluation of the SERVQUAL scales in a retailing setting. Advances in Consumer Research, 18 (1): 483-490. 
Giappiconi, T. 1995. Library evaluation and public policy: a French view. Journal of Librarianship and Information Science, 27(2): 99- 108.

Gilmore, A \& Carson, D. 1992. Marketing intelligence and planning. European Journal of Marketing, 10(7): 5-7.

Gronroos, C. 1990. Service management and marketing: managing the moments of truth in service competition. San Fansisco: Jossy Press.

Grove, SJ, Fisk, RP \& John, J. 2003. The future of services marketing: forecasts from ten services experts. Journal of Services Marketing, 17(2): 107-121.

Hair, JF., Anderson, RE., Tatham, RL. \& Black, WC. 1998. Multivariate data analysis 5th edition. Englewood Cliffs: Prentice-Hall.

Hamburg, M., Richard CC., Michael RW., Bommer. LR \& Ronald MW. 1974. Library planning and decision-making systems. Cambridge, Mass: MIT Press.

Harwood, N \& Bydder J. 1998. Student expectations of, and satisfaction with, the university library. The Journal of Academic Librarianship, 24(2): 161171.

Hernon, P \& Altman, E. 1996. Service quality in academic libraries. Norwood, NJ: Ablex Publishing.

Hernon, P \& Altman, E. 1998. Assessing service quality: satisfying the expectations of library customers. Chicago: American Library Association.

Hernon, P \& Altman, E. 1998. Assessing service quality: satisfying the expectations of library customers. Chicago: American Library Association.

Hernon, P \& Calvert, PJ. 1996. Methods for measuring service quality in university libraries in New Zealand. Journal of Academic Librarianship, 22: 387-391.

Hernon, P \& Calvert, PJ. 2005. E-service quality in libraries: exploring its features and dimensions. Library and Information Science Research, 27(3): 377-404. Hernon, P \& McClure, C. 1990. Evaluation and library decision making. Norwood, NJ: Ablex.

Hernon, P \& Nitecki, DA. 2001. Service quality: a concept not fully explored. Library Trends, 49(4): 687-708. 
Hofman,P \& Worsfold, E. 1996. Specification for resource description methods Part 2: selection criteria for quality controlled information gateways, Work Package 3 of Telematics for Research project DESIRE (RE 1004). Available: http://www.ukoln.ac.uk/metadata/desire/quality/quality.pdf (Accessed on 12 March, 2008).

lacobucci, D., Ostrom, A \& Grayson, K. 1995. Distinguishing service quality and customer satisfaction: the voice of the customer. Journal of Consumer Psychology, 4(3): 277-303.

Jamal, A \& Naser, K. 2002. Customer satisfaction and retail banking: an assessment of some of the key antecedents of customer satisfaction in retail banking. International Journal of Bank Marketing, 20(4):146-160.

Johnson, MD, Anderson, EW \& Fornell, C. 1995. Rational and adaptive performance expectations in a customer satisfaction framework. Journal of Consumer Research, 21(4): 695-707.

Kandampully, J. 2002. Innovation as the core competency of a service organization: the role of technology, knowledge and networks. European Journal of Innovation Management, 5(1): 18-26.

Kyrillidou, M. 1998. An overview of performance measures in higher education and libraries. ARL: A Bimonthly Newsletter of Research Library Issues and Actions from ARL, CNI and SPARC, 197: 3-8.

Ladhari, R. 2008. Alternative measures of service quality: a review. Managing Service Quality, 18(1): 65-86.

Lee, H., Lee, Y \& Yoo, D. 2000. The determinants of perceived service quality and its relationship with satisfaction. The Journal of Services Marketing, 14(3): 217-231.

LibQUAL $+{ }^{\mathrm{TM}}$ : defining and promoting library service quality. 2008. Available: http://www.LibQUAL.org/About/Information/index.cfm. (Accessed on 18 January 2008).

Linn, MW \& Linn SB. 1975. Narrowing the gap between medical and mental health evaluation. Medical Care, 13(7): 607-614.

Lovelock, C \& Wirtz, J. 2004. Services marketing: people, technology, strategy. Upper Saddle River NJ: Pearson Prentice Hall. 
Mano, H \& Oliver, RL. 1993. Assessing the dimensionality and structure of consumption experience: evaluation, feeling, and satisfaction. Journal of Consumer Research, 20 (3): 451-466.

Markham, WJ \& Aurik, JC. 1993. Shape up and ship out. Journal of European Business, 4 (5): 54-57.

Martensen, A \& Granholdt, L. 2003. Improving library users' perceived quality, satisfaction and loyalty: an integrated measurement and management system. The Journal of Academic Librarianship, 29(3): 140-147.

Moon, AE. 2006. LibQUAL+ ${ }^{\mathrm{TM}}$ at Rhodes University Library: An Overview of the First South African Implementation. In: Quality assurance in higher education. Available: http://eprints.ru.ac.za/234/01/Paper A-Moon-v5.pdf (Accessed on 03 March, 2008).

Morrison, L. 2004. Measuring service quality: a review and critique of research using SERVQUAL. International Journal of Market Research, 46(4): 479-97.

Nanayakkara, L. 2007. A comparative study on marketing of reader services in academic libraries in Asia: with special reference to India, Malaysia, Thailand and Sri Lanka. MLS thesis (unpublished). University of Colombo.

Newsome, PRH \& Right, GH. 1999. A review of patient satisfaction: concepts of satisfaction. Available: http://www.nature.com/bdj/journal/v186/n4/full/4800052a.html (Accessed 16 December, 2007).

Ngulube, P. 2005. Research procedures used by Master of Information Studies Students at the University of Natal in the period 1982-2002 with special reference to their sampling techniques and survey response rates: a methodological discourse. The International Information and Library Review, 37:127-143.

Nimsomboon, N \& Nagata, H. 2003. Assessment of library service quality at Thammasat University. Available: http://www.kc.tsukuba.ac.jp/divcomm/pdf/report0403.pdf. (Accessed on 23 February, 2008).

Nitecki, D. 1996. Changing the concept of measure of service quality in academic libraries. Journal of Academic Librarianship, 22(3): 181-190.

Nitecki, DA \& Hernon, P. 2000. Measuring service at Yale University's libraries. Journal of Academic Librarianship, 26(4): 259-73. 
Nunnally, J. 1967. Psychometric theory. New York: McGraw-Hill

Oliver, RL \& DeSarbo, WS. 1988. Response determinants in satisfaction judgments. Journal of Consumer Research, 14(4): 495-507.

Oliver, RL. 1977. Effect of expectation and disconfirmation on post-purchase product evaluations: an alternative interpretation. Journal of Applied Psychology, 62 (4): 480-486.

Oliver, RL. 1993. Cognitive, affective and attribute bases of the satisfaction response. Journal of Marketing Research, 20(3):418-431.

Parasuraman, A., Zeithaml, VA \& Berry, LL. 1985. A conceptual model of service quality and its implications for future research. Journal of Marketing, 49(4): 41-50.

Parasuraman, A., Zeithaml, VA \& Berry, LL. 1988. SERVQUAL: a multiple - item scale for measuring consumer perceptions of service quality. Journal of Retailing, 64(1): 12-40.

Parasuraman, A., Zeithaml, VA \& Berry, LL. 1994. Re assessment of expectations comparison standard in measuring service quality: implications for further research. Journal of Marketing, 58(1): 111-124.

Pritchard, SM. 1996. Determining quality in academic libraries. Library Trends, 44(3): 572-594.

Quinn, B. 1997. Adapting service quality concepts to academic libraries. The Journal of Academic Librarianship, 23: 359-69.

Robinson, S. 1999. Measuring service quality: current thinking and future requirements. Marketing Intelligence and Planning, 17(1): 21-32.

Rowley, J. 2002. Using case studies in research. Management Research News, 25(1):16-27.

Rust, RT \& Oliver, RL. 1994. Service quality: insights and managerial implications from frontier. In Rust, RT \& Oliver, RL (eds). Service quality: new directions in theory and practice. Thousands Oaks, CA: Sage: 1-19.

Sabath, RE. 1978. How much service do customers really want?. Business Horizons, 21 (2): 26-38. 
Sahu, AK. 2007. Measuring service quality in an academic library: an Indian case study. Library Review, 56(3): 234-243.

Schembri, S \& Sandberg, J. 2002. Service quality and the consumer's experience: towards an interpretative approach. Marketing Theory, 2(2): 189-205.

Schneider, B \& White, SS. 2004. Service quality: research perspective. Thousands Oaks, CA: Sage.

Shi, X \& Levy, S. 2005. A theory-guided approach to library services assessment. College and Research Libraries, 66(3): 266-277.

Shi, X., Holahan, PJ \& Jurkat, P. 2004. Satisfaction formation processes in library users: understanding multi-source effects. The Journal of Academic Librarianship, 30(2): 122-131.

Sinyenyeko-Sayo, NC. 2007. Improving library services through the application of business performance concepts. Available: http://etd.uwc.ac.za/usrfiles/modules/etd/docs/etd gen8Srv25Nme4 324 5 1188477605.pdf (Accessed on 12 March 2008).

Taylor, SA \& Baker, TL. 1994. An assessment of the relationship between service quality and customer satisfaction in the formation of consumers' purchase intentions. Journal of Retailing, 70(2): 163-78.

TCRP-Report-47 1999. A handbook for measuring customer satisfaction and service quality. Available:

http://gulliver.trb.org/publications/tcrp/tcrp_rpt_47-d.pdf. (Accessed on 19 November, 2007).

Thompson, AM \& Kaminski, PF. 1993. Psychographic and lifestyle antecedents of service quality expectations: a segmentation approach. Journal of Services Marketing, 7(4): 53-61.

Ting, DH. 2004. Service quality and satisfaction perceptions: curvilinear and interaction effect. International Journal of Bank Marketing, 22(6):407-20.

Tse, DK \& Wilton, PC. 1988. Models of consumer satisfaction formation: an extension. Journal of Marketing Research, 25(2): 204-212.

Tuomi, V. 2001. Quality of academic library services: a customer point of view, EGPA 5-8 September 2001/ Permanent study group 2, Productivity and quality in the public sector. Available: 
http://soc.kuleuven.be/io/egpa/qual/vaasa/paper_vaasa_tuomi.pdf (Accessed on 10 March, 2008).

Vargo, SL \& Lusch, RF. 2004. Evolving to a new dominant logic for marketing. Journal of Marketing, 68(1): 1-17.

Walters, WH. 2003. Expertise and evidence in the assessing library service quality. Performance Measurement Metrics, 4(3): 98-102.

White, MD \& Abels EG.1995. Measuring service quality in special libraries: lessons from service marketing. Special Libraries, 86:(1): 36-45.

White, MD., Abels, EG \& Nitecki, D. 1994. Measuring customer satisfaction and quality of service in special libraries. Washington: Special Libraries Association.

White, MD., Abels, EG \& Nitecki, D. 1994. Measuring customer satisfaction and quality of service in special libraries. Washington: Special libraries Association.

Wilson, G \& Sasse, M. 2004. From doing to being: getting closer to the user experience. Interacting with Computers, 16: 697-705.

Woo, H. 2005. The 2004 user survey at the University of Hong Kong Libraries. College and Research Libraries, 66(2): 115-135.

Woodruff, RB., Cadotte, ER \& Jenkins, RL. 1983. Modeling consumer satisfaction process using experience-based norms. Journal of Marketing Research, 20(3): 296-304.

Wright, L. 1995. Avoiding service marketing myopia. In Glynn, W and Barnes, J. (eds.), Understanding services management. Chichester: Wiley \& Sons: 3356.

Zeithaml, VA \& Bitner, MJ. 1996. Services Marketing. New York: McGraw Hill.

Zeithaml, VA., Berry, LL \& Parasuraman, A. 1993. The nature and determinants of customer expectations of service. Journal of the Academy of Marketing Science, 321(1): 1-12.

Zhao, X., Xie, J \& Leung, J. 2002. The impact of forecasting model selection on the value of information sharing in a supply chain. European Journal of Operational Research, 142(2): 321-344. 